\title{
Halakhah, Theology and Psychology: The Case of Maimonides and Obadiah the Proselyte
}

\author{
Eliezer Diamond
}

לכבוד מורינו ורבינו הרב הפרופסור יעקב רוט

Our sages famously say, אין לדיין אלא מה שעיניו רואות, "a judge should rule solely in accordance with what is before him". Talmudic sources invoke this principle in order to limit the realm of a judge's responsibility and authority, ${ }^{2}$ directing judges to issue rulings based on empirical evidence rather than speculation. ${ }^{3}$ There are instances, however, in which the Talmud authorizes and encourages a judge to transcend normative legal protocols. In monetary cases, the Talmud endorses the use of judicial discretion if one is inclined to believe testimony or evidence that is not technically admissible. ${ }^{4}$ Similarly, in criminal cases, judges are advised to recuse themselves from cases in which they would be forced to issue a ruling based on testimony or stipulations that they believe to be false though they cannot prove this. ${ }^{5}$

It is noteworthy that the originally restrictive principle of אין לדיין was interpreted expansively in post-Talmudic halakhic discourse. As such it served as a justification for and crystallization of an emerging consensus: namely, that

1 This statement appears three times in the Bavli; its import varies according to context. Its use in b. Sanh. 6a comes closest to the sense in which I am interpreting it. See Maimonides' formulation of the passage in Sanhedrin in his halakhic code Mishneh Torah (henceforth: MT), Laws of the Sanhedrin, 23:9.

2 See b. Sanh. 6a.

3 b. B. Bat. $131 \mathrm{a}$ and b. Nid. $20 a$.

4 See b. Ketub. 85a. In Maimonides' formulation of this legal principle in MT, loc. cit., 24:1 he states, "The matter is placed in the hands of the judge in accordance with what he sees as being the appropriate judgment."

5 MT, loc. cit., 24:3. 
in fact poseqim have the right - and, at times, obligation — to use judicial discretion to reach rulings at variance with black-letter law. In this reading, the "seeing" in question is insight rather than knowledge. According to this reading the principle of אין לדיין should then be translated as "a judge should rule in accordance with his perceptions." 6

This principle, in its post-Talmudic sense, became relevant not only in criminal and civil cases but in other areas of halakhah as well. In particular, a skilled poseq was expected to discern larger, often unspoken, issues underlying the question being asked. To use therapeutic language, one needed to go beyond the presenting problem to identify and address the deeper one. This skill has proven indispensable to poseqim throughout the ages. It is still recognized as being crucial to issuing rulings that are equitable and compassionate as well as firmly grounded in rabbinic sources.

The great scholar and sage Maimonides (1138-1204) was particularly adept at perceiving the true intentions and deeper concerns of litigants and petitioners in cases that either came before him directly or were referred to him. Consequently, he was able to combine insight with adjudicatory virtuosity to arrive at rulings that were both halakhicly rigorous and humane. ${ }^{7}$

I wish to analyze a Maimonidean responsum ${ }^{8}$ that demonstrates acuity in discerning and addressing the unstated concerns of the questioner. The question, addressed to him by a convert named Obadiah, is whether or not, as someone not born a Jew, he should use phrases like "the God of our ancestors" in his prayers-a question that, as we shall see, was discussed in Talmudic sources.

6 See, for example, the following statement by Maimonides' son Abraham in his responsa (No. 97): "I say that a judge who rules only in accordance with what is already on record is frail and feeble. This approach is a rejection of the rabbinic dictum, 'A judge rules only in accordance with what is before him.' And it must not be so. Rather, although the fundamental legal principles have been codified, a judge or jurist must weigh them in accordance with each case as it comes before him, to draw an analogy between one case and another, and to extract specific rulings from the fundamental laws." See also the following footnote.

7 In one of his responsa, Maimonides cites the principle of אין לדיין as a basis for limiting the applicability of a Talmudic ruling despite the absence of such a qualification in the Talmud. In doing so he undermines the claim of an unscrupulous litigant, thereby ensuring an equitable verdict; see Joshua Blau, ed. and trans., Maimonides' Responsa [Heb.], 3 vols. (Jerusalem: Hevrat Meqișe Nirdamim, 1961), No. 365 (2:639-641). The numerical designations and pagination accompanying subsequent mention of specific Maimonidean responsa refer to Blau's edition.

8 No. 293 (2:548-550); Isaac Shilat, ed. and trans., Maimonides' Epistles [Heb.], 2 vols. (Jerusalem: Ma'aliyot Press, 1988), 1:233-235. 
As has been noted by others, ${ }^{9}$ it seems likely that this query reflected a broader concern on Obadiah's part about whether he could claim to be as fully and unquestionably Jewish as a born Jew. Anxiety and uncertainty about this question would be understandable, given that Rabbinic Judaism manifests some ambivalence toward proselytes, both through negative characterizations ${ }^{10}$ and through halakhic rulings that seemingly impute an inferior status to converts. ${ }^{11}$ Moreover, we know of another query from the self-same Obadiah ${ }^{12}$ in which, having been told by his teacher that Islam was an idolatrous religion, he seeks Maimonides' view on the matter. The fact that, in his teacher's view, he had formerly been an idolater could have only contributed to a sense of inferiority ${ }^{13}$

This responsum has been studied by numerous scholars from various perspectives. ${ }^{14}$ My focus will be an analysis of the stratagems and techniques that Maimonides uses to address Obadiah's fears. A translation of the responsum

See, for example, James A. Diamond, Converts, Heretics, and Lepers (Notre Dame: University of Notre Dame Press, 2007), 11-31.

10 Such as the dictum, "proselytes are as injurious to Israel as a scab" (b. Qidd. 7ob and parallels). The Bavli reports this teaching in the name of the Amora R. Helbo; in Kallah Rab. 2:4 it is cited as a Tannaitic tradition.

11 See, for example, y. Qidd. 3:12, 64c, b. Qidd. 72b-73a and Shulhan Arukh, Even ha-Ezer 4:22.

12 No. 448 (2:725-728; Shilat, 1:238-241). We know of one other Maimonidean responsum addressed to a proselyte named Obadiah; see No. 436 (2:714-716; Shilat, 1:236-238).

In the superscription and section 1 of the responsum under discussion reference is made to multiple queries on the part of Obadiah (but see $n$. 17 below). Using the associative principle, the three responsa addressed to a convert named Obadiah can be linked to each other. Both 293 (A) and 448 (B) address matters pertaining to the status of converts. In both 448 (B) and 436 (C) the inquirer Obadiah mentions his teacher, who in no uncertain terms "corrects" him. A is related to B, and B is related to C; hence it follows that A and $\mathrm{C}$ are related as well, and that all three responsa are addressed to a single individual.

13 It should be noted that making statements denigrating the former status of a convert is specifically forbidden; see b. B. Meș. $5^{8 \mathrm{~b}}$.

14 See Lawrence Kaplan, "Maimonides on the Singularity of the Jewish People," Daat 15 (1979): English section, v-xxvii; Isidore Twersky, Introduction to the Code of Maimonides (Mishneh Torah) (New Haven: Yale University Press, 1980), 485-486; Menachem Kellner, Maimonides on Judaism and the Jewish People (Albany, NY: SUNY Press, 1991), 49-57, esp. 50-51, 53; Menachem Lorberbaum, "Maimonides' Letter to Ovadyah: An Analysis," S'vara 3, no. 1 (1993): 57-66; James A. Diamond, "Maimonides and the Convert: A Juridical and Philosophical Embrace of the Outsider," Medieval Philosophy and Theology 11, no. 2 (2003):125-146; idem, Converts, Heretics, and Lepers (Notre Dame: University of Notre Dame Press, 2007), 11-31; Moshe Halbertal, Maimonides: Life and Thought, trans. Joel Linsider (Princeton: Princeton University Press, 2014), 208-216, esp. 215-216. I have not seen Philip Matoff Posner, "Maimonides' "t'shuva" to Ovadyah the Proselyte," ccar Journal 6o, no. 3 (2013): 185-202. 
from the Hebrew ${ }^{15}$ follows; ${ }^{16}$ I have divided it into numbered sections to which I will refer in my commentary and analysis by citing section numbers in parentheses where relevant.

[Superscription:] The following are inquiries addressed to our master, Rabbi Moses of blessed memory, by Obadiah the righteous proselyte and his responses: ${ }^{17}$

1. Thus said Moses the son of Rabbi Maimon of Spain - may mention of this righteous man bring blessing - who was among those exiled from Jerusalem:

2. We have received ${ }^{18}$ the inquiries of our teacher and master Obadiah, the wise and discerning proselyte, may the Lord reward him for his deeds, and may he receive full recompense from the Lord, the God of Israel, under whose wings he has sought shelter. ${ }^{19}$

3. You have inquired concerning the [the wording you should use for the following] blessings and prayers when you recite them in private

15 All the versions of this responsum presently available to us are in Hebrew. Maimonides often wrote his responsa in Judeo-Arabic, and some responsa that were previously known in a Hebrew version we now know were written originally in Judeo-Arabic. See the first page of Blau's introduction in volume 1 of Maimonides' Responsa (the introduction is not paginated).

16 A number of English translations are available. See Nahum N. Glatzer, ed., The Judaic Tradition, rev. ed. (Springfield, NJ: Behrman House, 1969), 395-396; Isadore Twersky, A Maimonides Reader (New York: Behrman House, 1972), 475-476; Menachem Lorberbaum, "Maimonides' Letter," 64-66; Diamond, Converts, 12-14; Levi Cooper, "From the Classics: 'God of our Ancestors': Biological Ancestry and Spiritual Roots in the Prayers of Converts," Building Jewish Identity 7, no. 2 (Winter 2009), https://www.lookstein.org/journal/classics -god-ancestors-biological-ancestry-spiritual-roots-prayers-converts/. Only Lorberbaum translates the responsum in its entirety. The translation provided here is my own; it is based mainly on the version of the responsum published by Blau. I will occasionally mention and discuss variants mentioned in Blau's and Shilat's notes.

17 Some manuscripts: "This is a response to an inquiry sent from the Land of Israel by a righteous proselyte to which the gaon our master Moses of blessed memory responded"; see Blau, 2:548, n.1.

18 אליעו אלינו Presumably Maimonides is using the royal "we" here; cf. n. 4o below. Shilat, 1:233 n. 2, mentions the variant.

19 Maimonides cites Ruth 2:12 but in the third person rather than the second person of the original verse. Beginning with the rabbinic period the image of entering under the wings of the Divine Presence is used as a metaphor for formal conversion to Judaism. See, for example, b. Šabb. 31a. Maimonides uses this metaphor for conversion throughout MT; see Laws of Character Traits 6:4; Laws of Forbidden Relations 13:4; Laws of Kings and their Wars 8:5. See also his Sefer Ha-Mitsvot, Negative Commandments, Commandment 252. Maimonides uses this expression several times in this responsum; see sections 2, 5, 9 and 11. 
or with the congregation [given that you are a proselyte]:Should you say "Our God and God of our ancestors", 20 "The One who has sanctified us through His commandments and commanded us," ${ }^{21}$ "The One who has distinguished us,"22 "The One who has chosen us,"23 "[the land] that You gave as an inheritance to our ancestors," ${ }^{4}$ "You who brought us forth from the land of Egypt,"25 "The One who performed miracles for our ancestors," 26 and other such phrases.

4. You should ${ }^{27}$ say all this in the prescribed fashion. Change nothing; rather, it is appropriate that you recite the blessings and prayers

20 The reference here is to the opening words of the Amidah, ברוך אתה ה' אלוקינו ואלוקי "אבותינו, "Blessed are You, Lord, our God and the God of our ancestors."

אשר קדשנו במצותיו וצונו, the opening formula of all blessings recited prior to the fulfillment of a commandment. Compare the phrase in the Kiddush recited on Friday night, "who has sanctified us with His commandments and has favored us."

אשר הבדילנו. Shilat, 1:233 n. 6, observes that this phrase does not appear in any liturgical tradition presently known to us. An almost identical phrase, והדילדילנו משן התועים, is found in the so-called קדושה דסידרא (see b. Soțah 49a), versions of which appear in the daily morning prayers, the afternoon Shabbat service, the evening service at Shabbat's conclusion, and after the reading of the Book of Esther on Purim Eve and the Book of Lamentations on the eve of Tisha Be-Av. Shilat, loc. cit., states that this phrase appears in Maimonides' version of this prayer as recorded in his Seder Tefillot Kol Ha-Shanah, which is appended to the second book of $\mathrm{MT}$, Sefer Ahavah. This is indeed the reading in the standard printed editions of мт. However, Shabbetai Frankel's edition and the Oxford manuscript of Seder Tefillot published by Daniel Goldschmidt (Mehqerei Tefillah u-Fiyyut

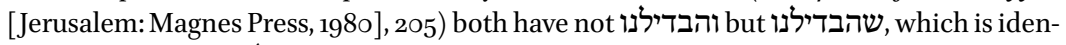
tical in meaning to אשר הבדילנו.

This phrase echoes Lev 20:26: "For I have singled you out (ואבדיל אתכם) from among all the nations to be mine." The Havdalah ceremony at the conclusion of Shabbat is centered on this theme.

23 אשר בחר בנו. This phrase appears in various forms in the initial blessing recited by one being called to the Torah, the evening Kiddush for festivals, the festival Amidot, the blessing before the morning Shema, and elsewhere.

24 שהנחלת את אבותינו. This phrase appears in Birkat ha-Mazon and the שרכה מעין שלש. Many liturgical traditions have שהנחלת לאבותינות. Maimonides' Seder Tefillot has the

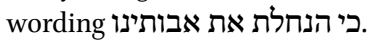

25 שהוצאתנו מארץ מצרים; cf. Deut 9:28. This phrase appears in Birkat ha-Mazon and, with variations, elsewhere in the liturgy. In Exodus and Deuteronomy this phrase appears in the third person; see, for example, Exod 13:16.

26 שעשה נסים לאבותינו. This phrase is to be found in the blessing accompanying the lighting of the Hannukah lights and the reading of the Megillah and is found in variant forms elsewhere in the liturgy.

27 יש לך. Although this phrase sometimes means "you may" or "you can," the conclusion of the sentence makes it clear that Maimonides is speaking prescriptively. 
just as they are recited by those born as Jews, ${ }^{28}$ both when you are engaged in private prayer and when you are serving as the prayer leader. ${ }^{29}$

5. The basis for this is that Abraham our Father taught the masses, ${ }^{30}$ enlightened them, and made known to them doctrinal truth [i.e. monotheism] and [the fact of] God's unity. He rejected idolatry and abolished its practices, and he gathered many under the wings of the Divine Presence. ${ }^{31} \mathrm{He}$ provided them with instruction and guidance. He charged his descendants and subsequent "members of his household" 32 with keeping the ways of the Lord forever, as Scripture states, "For I have singled him out, that he may instruct his children and his posterity ${ }^{33}$ to keep the way of the Lord [by doing what is just and right]." ${ }^{34}$

28 אזר and often appear conjunctively in verses indicating restrictions or obligations that apply equally to both; see Exod 12:49; Lev 16:29 and 18:26 (see also 17:913, 20:2 and 22:18); Num 15:15-16, 26, 29-30 and 19:10. In Lev 19:34 the conjunction of these terms is used to emphasize that the obligations to deal fairly and kindly with sojourners and to do so with Israelites are equally binding.

29 See $n .54$ below.

30 כל העם . Maimonides generally uses this phrase to refer to Jews. He uses this phrase in the broader sense only in connection with Abraham's proselytizing mission, here and in MT, Laws of Idolatry 1:2-3. Cf. MT, Laws of Repentance 9:2 (concerning the Messiah): “Therefore he will teach the masses (כל העם) and instruct them in God's ways, and all the nations will come to hear his words." Presumably כלדעם refers there to the Jewish people as opposed to "all the nations."

31 As mentioned above, in rabbinic sources this phrase refers to conversion. This sense of the phrase would seem to constitute an anachronism in the present context. See the discussion of this problem below.

32 בני ביתו . I have translated the phrase literally but with quotation marks for the following reason. Maimonides is alluding to Gen 18:19, which he cites immediately afterwards, in which God speaks of Abraham as instructing בניו וביתו אחריו to "keep the ways of the Lord etc." In context the phrase בניו וביתו אחריו seems to mean, as the New JPS translation has it, "his children and his posterity." In rabbinic literature בני ביתו refers to one's household, sometimes specifically in the familial sense and sometimes more inclusively, ביתו referring to other household members as well. Maimonides, however, understands in Gen 18:19 as referring to Abraham's disciples and those of subsequent generations who adhere to his teachings, as he makes clear in section 6 below and in MT, Laws concerning Idolatry 1:3, which I cite further on. Cf. Maimonides' remarks in Responsum 164 (2:313-314): “Only those who adopt one's religion are considered one's household, as is said concerning the members of Abraham's household. They were the ones who embraced his views and adopted his faith. One's slaves and workers who are deniers are not considered members of one's household."

33 וביתו; see the previous note.

34 Gen 18:19. 
6. Therefore, throughout the generations, whoever converts to Judaism and whoever ${ }^{35}$ confesses the unity of the Divine Name, as it is prescribed in the Torah, is counted among the disciples of Abraham our Father, peace be upon him. They are all members of Abraham's household, ${ }^{36}$ and he it is who brought them back to the good. ${ }^{37}$

7. Just as he restored his contemporaries [to the true faith] through his oral instruction and his teachings, he [prospectively] brought future generations [to true faith] through the testament he left to his children and household after him. Thus, Abraham our Father, peace be upon him, is the father to those of his descendants who are worthy in that they follow in his ways, as well as the father of his disciples and of all those ${ }^{38}$ who become proselytes.

8. Therefore, you shall pray, "Our God and God of our ancestors," because Abraham, peace be upon him, is your [spiritual] father. And you shall pray, "[the land that] You have given as an inheritance to our ancestors," for the land was given to Abraham [and consequently to you as well], as it is said, "Up, walk around the land, through its length and its breadth; for I will give it to you."39

9. However, as to the words, "You who brought us forth from the land of Egypt" or "You who performed miracles for our ancestors" - these you may change, if you wish, and say, "You who brought forth Israel from the land of Egypt" and "You who performed miracles for Israel." If, however, you do not change them, no harm has been done. As a consequence of your having come under the wings of the Divine Presence and having attached yourself to Him, there is no distinction between us and you, ${ }^{40}$ and all miracles performed for us have

See n. 88.

36 ובני ביתו הם כולם; see n. 32.

37 Maimonides' talk of return and restoration in this and the following section is based on his reconstruction of the origins of idolatry in MT, Laws concerning Idolatry, 1:1-2. In his telling, Adam and his descendants had full and true knowledge of God until the generation of Enosh, at which point the masses were gradually led astray through the adoration and eventual worship of heavenly bodies such as the sun and the moon. Abraham rediscovered the truth that had been forgotten and restored this knowledge to his adherents.

$38 \quad$ See n. 88.

39 Gen 13:17.

40 אין כאן הפרש בינינו ובינך. See n. 18 above. Here it seems likely that, rather than being a self-referential use of the royal "we", "us" refers to native-born Jews. This is certainly true of the "us" in the first sentence in section 10: "For the Torah has been given to us and to the proselytes." 
been performed, as it were ${ }^{41}$ for both us and you. Thus is it said in the Book of Isaiah, "Let not the foreigner say, who has attached himself to the Lord, "The Lord will keep me apart from His people." 42 There is no difference whatsoever between you and us.

10. You shall certainly say the blessing, "Who has chosen us," "Who has given us," "Who has given to us as an inheritance,"43 and "Who has distinguished us", for the Creator, may He be extolled, has indeed chosen you, set you apart from the nations and given you the Torah. For the Torah [has been given] both to us and to proselytes, as it is said, "One law shall there be both for you of the congregation, and also for the stranger that sojourns with you, a law forever in your generations; as you are, so shall the stranger be before the Lord."44

11. Know that those of our ancestors who left Egypt were mostly idolaters; they had mingled with the Egyptians and followed their practices, until the Blessed Holy One sent Moses our Teacher, the su-

41 כאלו. Shilat, 1:234, in his note to line 15, notes the variant באלו ; these two words are of course virtually indistinguishable orthographically. It may be that according to this reading the phrase וכל הנסים שנעשו באלו לנו ולך נעשו should be translated as "and all the miracles performed for them were [also] performed [both] for us and for you," the antecedent of "them" being the Israelites who experienced these miracles personally. Thus, the use of באלו, literally "to them", in connection with those past generations who lived in an age of miracles and לנו, "for us", for later generations who did not. Indeed, given that miracles are not supra-temporal concepts like chosenness and covenant but rather events that take place in real time, subsequent generations can claim that the miracles were performed in their behalf only in the broader sense. It is this fact that lies behind the insistence in the passage in the Haggadah that although we ourselves were never slaves in Egypt we are ultimately the beneficiaries of the liberation from bondage long ago. If באלו is the correct reading and my interpretation an accurate one Maimonides is not, as the reading כאלו would suggest, implicitly acknowledging the weakness of his case in the very moment in which he presents it. On the contrary, he is making the rather persuasive argument that native-born Jews are no more entitled to speak of the miracles of the past being done to or for them than are proselytes.

42 Isa $56: 3$.

43 אשר הנחילנו. I could not find this phrase anywhere else in Maimonides' writings, including his Seder Tefillot. In мт, Laws of Shabbat 29:2, Maimonides records the liturgical formula for the Friday night Kiddush as including the phrase, "who (אשר) sanctified us with His commands and favored us and who granted us as our inheritance (הנחילנו) His holy Sabbath with love and favor." Perhaps Maimonides has that phrase in mind and is citing it elliptically, אשר ... הנחילנו. However, the context suggests that the inheritance in question is the Torah rather than Shabbat. This phrase does not appear in Shilat's recension; see Shilat, 1:234, line 18.

Num 15:15. 
preme prophet, and $\mathrm{d}^{45}$ separated us from the nations and brought us under the wings of the Divine Presence, us and all proselytes, and gave to all of us one Law.

12. Do not consider your status as inferior. While we are descended from Abraham, Isaac, and Jacob, yours is a direct relationship with Him through whose word the world was created. This is made explicit in [the Book of] Isaiah: "One shall say, I am the Lord's, and another shall call himself by the name of Jacob."

13. And there is support in tractate Bikkurim for all that we have told you regarding [how you should recite the] blessings, namely that you should not deviate [from the accepted liturgical forms]. The mishnah there states: ${ }^{47} \mathrm{~A}$ proselyte is obligated to bring first fruits to the Temple but does not recite the requisite declaration ${ }^{48}$ because he is disqualified from reciting the verse "[the land] that the Lord swore to our fathers to assign us." ${ }^{39}$ And when he prays in private he recites [in the first blessing of the Amidah] "our God and the God of Israel's ancestors." And when he prays in public he recites, "our God and the God of your ancestors." ${ }^{50}$ This is the view stated anonymously in the mishnah. It is R. Meir's view, ${ }^{51}$ and the halakhah is not in accordance with his position but rather in accordance with what is explained in the Jerusalem Talmud. ${ }^{52}$ It is stated there: It was taught in the name of R. Judah that a proselyte himself offers first fruits and recites the declaration. Why is this so? [Because Scripture states]: "I have made you the father of a multitude of nations"; 53 in the past you were the father of Aram; from now forward you will be the father to all of humankind. R. Joshua b. Levi says: The halakhah is in accordance with R. Judah. A case came before R. Abbahu and he ruled in accordance with R. Judah. ${ }^{54}$

It is not clear in this and the following phrases whether the subject is God or Moses. If the latter is the case a more accurate translation would be "and he [i.e. Moses] separated etc."

$46 \quad$ Isa $44: 5$.

$47 \quad$ m. Bik. 1:4.

48 Deut 26:3, 5-10.

49 Deut 26:3.

$50 \quad$ In Blau (2:550):אלוקינו ואלוקי אבותינו. This is clearly the result of a scribal error; see n. 12 there.

$5^{1} \quad$ See further on.

52 y. Bik. 1:4, 64a.

53 Gen 17:4.

54 Note that R. Judah and R. Joshua b. Levi address only the issue of the first fruits declara- 
14. Observe - it has been made clear to you that one should recite "that the Lord swore to our fathers to assign us," 55 and that Abraham is the father to you, to us, and to all the righteous [who] follow in his ways. The same is true of the other blessings and prayers; you should change nothing.

[Postscript:] Thus wrote Moses son of Maimon of blessed memory.

On its face, Obadiah's inquiry concerns a matter of halakhah and nothing more, for which a straightforward halakhic response would suffice. However, from the content and structure of his response it appears that Maimonides understood Obadiah's inquiry to be fundamentally an ontological one: is a proselyte as fully Jewish as one who is born a Jew? To use a helpful distinction formulated by Ethan Tucker, Obadiah is apparently seeking confirmation that his halakhic status as a Jew is in absolute accordance with his unconditional embrace of Jewish identity in all its fullness. With this in mind, Maimonides crafts the structure and content of his response with an eye towards reassuring Obadiah

tion and not that of the appropriate liturgical formula for converts. However, as a number of commentators point out (see, for example, the commentary of the 15th-16th-century sage R. David ibn Zimra, known as Radbaz, to Mт, Laws of First Fruits 4:3), first fruits were no longer being brought in the days of R. Abbahu, a third-generation Palestinian Amora, who was being consulted on a matter of practical halakhah. It therefore follows that he was ruling on the liturgical issue.

Maimonides rules in accordance with R. Judah regarding the declaration question both in his Mishnah commentary ad. loc. and in MT Laws of First Fruits loc. cit. To the best of my knowledge, his only mention of the prayer issue is in the responsum under discussion. R. Yosef Kafih (Yosef Kafih, ed. and trans., Maimonides'Mishnah Commentary [Heb.], 3 vols. [Jerusalem: Mossad Harav Kook, 1963], 1:263 n. 13) points out that the section of Maimonides' Mishnah commentary containing his ruling and the citation of $y$. Bik. is missing from the first recension. He speculates that this passage was added after Maimonides wrote his response to Obadiah.

Medieval Ashkenazic authorities debated both the meaning of the Yerushalmi and whether in fact a convert was permitted to use the same language in his prayers and blessings as born Jews. In some communities the adoption of the prohibitive view led to the practice of prohibiting converts from serving as prayer leaders or leading a zimmun before Birkat ha-Mazon; see Tosafot's commentary on b. B. Bat. 81a s.v. למעוטי, and Mordechai's commentary on b. Meg., par. 786 . However, the consensus was to adopt the affirmative view and consequently to allow converts to lead both.

For a summary of the interpretational issues and views regarding the passage in y. Bik., see Saul Lieberman, Tosefta Ki-Fshuțah, 10 vols., 3rd ed. (Jerusalem: Jewish Theological Seminary, 2001), 2:823-825. A survey of rulings on the prayer issue can be found in Menahem Mendel Kasher, ed., Talmudic Encyclopedia [Heb.], 40 vols. so far (Jerusalem: Yad Harav Herzog, 1947-), s.v. ג (6:258-259). 
and validating his status as a Jew to the fullest extent possible. In addition to ruling on the halakhic question and citing Talmudic sources to buttress his decision, Maimonides provides a theological rationale for his ruling and marshals scriptural verses to offer Obadiah support and encouragement.

Let us now consider the structural, rhetorical, and substantive strategies used by Maimonides in the service of his project:

1. A nuanced wording and ordering of his rulings and the relevant Talmudic sources $(4,8-10,13-14)$.

2. A restatement of Maimonides' description of Abraham's mission in Mishneh Torah, Laws concerning Idolatry ch. 1, adapted in order to serve as confirmation of Obadiah's full status as a Jew $\left(5^{-7}, 11\right)$.

3. Homilies that augment his halakhic and theological arguments in an effort to compensate for and/or divert attention from their flaws $(9,12)$. Although there is some overlap, one can say that the first strategy focuses on law, the second on theology, and the third on psychology.

\section{Law}

A glance at the rabbinic sources cited by Maimonides (13) makes it clear that there was hardly unanimity about whether a convert should recite the first fruits declaration and use the same liturgical language recited by native Jews. The anonymous mishnah cited by Maimonides excludes a convert from doing either. Moreover, an Amoraic comment in the Bavli ${ }^{56}$ seems to assume that the mishnah's view is dispositive. It is only in the Yerushalmi that we encounter the inclusive view of R. Judah with regard to the declaration, which by implication constitutes an inclusive view regarding the liturgical question as well. ${ }^{57}$ Given the consensus among Maimonides' predecessors and contemporaries that the view of the Yerushalmi should be adopted only when not in conflict with the Bavli or when serving as an explanation or clarification of a statement in the Bavli, ${ }^{58}$ one would have expected Maimonides to rule in accordance with the Mishnah.

56 b. Mak. 19a. In the midst of a discussion of whether the first fruits declaration is indispensable to the fulfillment of the mitsvah of bringing first fruits R. Ashi, the fifth-century Babylonian Amora, cites the fact that a proselyte does not recite the declaration as evidence that it is not.

57 It should be noted that a number of Amoraim cited in the Yerushalmi passage clearly assume the view of the Mishnah to be dispositive. Moreover, the Tosefta records R. Judah as exempting converts from the first fruits declaration (t. Bik. 1:2).

$5^{8}$ See Menachem Elon, Jewish Law: History, Sources, Principles, trans. Bernard Auerbach and 
It is true that Maimonides himself sometimes ruled in accordance with the Yerushalmi against the Bavli. ${ }^{59}$ However, assuming that Obadiah was sufficiently learned ${ }^{60}$ to know that, when adjudicating between the views of the Bavli and the Yerushalmi, poseqim - including Maimonides-generally followed the Bavli, he would likely see a ruling based on a passage in the Yerushalmi contravening an anonymous mishnah as being less than robust. Even if Obadiah was not aware of this principle, he might well have been troubled by the very fact that the right of converts to recite the established liturgical formulae was a matter of debate. It seems likely that Obadiah was already aware of this; presumably, it was this knowledge that led him to seek Maimonides' counsel. It may even be that he had already been told by his teacher or someone else not to use standard liturgical language.

Maimonides' formulation of his ruling and his presentation of the Talmudic sources suggest an intent to minimize any negative implications that either might occasion. He begins by affirming unconditionally Obadiah's right to use the standard liturgical formulas (4), giving no indication that in fact in some instances it might be appropriate for Obadiah to recite a different version of the liturgy; this he saves for later (9). A presentation of the Talmudic sources, which indicate that the inclusive view championed by Maimonides was far from unanimous, is left until the very end of the responsum (13). Maimonides makes no mention at all of the passage in the Bavli that implies the restrictive view. ${ }^{61}$ Moreover, he makes no reference to the discussion in the Yerushalmi

Melvin J. Sykes, 4 vols. (Philadelphia: Jewish Publication Society, 1194), 3:1097-1098 and especially n. 68 on p. 1098.

59 For a discussion of Maimonides' occasional practice of adopting the Yerushalmi's ruling rather than the Bavli's, and a debate as to whether his view on this question shifted over time, see Michael Guttmann, "The Decisions of Maimonides in his Commentary on the Mishna," HUCA 2 (1925): 230-231; Aharon Adler, "Maimonides' Stance toward the Jerusalem Talmud" [Heb.], in Memorial Volume for R.Joseph ben David Kafih [Heb.], ed. Henil Seri and Zohar Amar (Ramat Gan: Bar-Ilan Press, 2001), 202-235; Dror Fixler, “Maimonides' Stance toward the Jerusalem Talmud as Reflected by His Commentary to Tractate Pe'ah" [Heb.], Netu'im 16 (2010): 95-109.

6o Maimonides addresses Obadiah as "our teacher and master Obadiah, the wise and learned proselyte" (2). Maimonides' inclusion of the Talmudic material in his responsum suggests both that Obadiah would be interested in the Talmudic basis for Maimonides' ruling and that he would be capable of understanding it.

61 The 17th-18th-century sage R. Judah Rosanes, in his commentary to MT, Mishneh laMelekh, challenges Maimonides' ruling based on the passage in Makkot. Interestingly, the 13th-century Provencal commentator Menahem ha-Meiri, in his commentary to b. Mak. 19a (Bet Ha-Behirah al masseket Makkot, s.v. הגר), cites almost verbatim Maimonides' ruling without addressing the Bavli's statement to the contrary.

It may be that Maimonides ignores the passage in the Bavli because of his tendency to minimize the juridical relevance of Talmudic statements appearing in the context of 
preceding the section he quotes in which the restrictive view is assumed to be normative, nor to the Tosefta that records R. Judah's view as being restrictive. ${ }^{62}$ On the other hand, he seeks to vitiate the authority of the mishnah by identifying it as the view of a single Tanna, R. Meir, rather than the majority view. This last claim is not without foundation, ${ }^{63}$ but is not explicit in the Yerushalmi. After presenting the mishnah and the Yerushalmi, Maimonides concludes by reaffirming his inclusive ruling (14).

\section{Theology}

Maimonides' second strategy was to treat Obadiah's halakhic question as reflecting an ontological one: was Obadiah entitled to view himself as being as fully Jewish as his fellow Jews? Maimonides answers this question in the affirmative by framing Jewish identity theologically rather than ethno-historically. He does so in four different ways.

\section{Abrahamic Discipleship}

According to a midrashic tradition, Abraham and Sarah proselytized among the inhabitants of $\operatorname{Haran}^{64}$ and beyond. ${ }^{65}$ It is presumably this tradition that underlies R. Judah's citation of Genesis 17:4, in which God promises Abraham, "you shall be the father of a multitude of nations," as the basis for his view that converts recite the first fruits declaration. ${ }^{66} \mathrm{He}$ apparently understands the "multitude of nations" as being specifically those among the nations who

argumentation rather than as explicit rulings. A discussion of this question is beyond the scope of this article.

62 t. Bik. 1:2.

63 The third-century Amora R. Yohanan attributes anonymous statements in the Mishnah to R. Meir (b. Sanh. 86a) — though he may be referring to the formulation rather than the content of these rulings. Based in part on this tradition, the Bavli, when finding a teaching of a named Tanna in conflict with the Mishnah, often resolves the conflict by attributing the mishnah to R. Meir. In doing so the Bavli weakens the mishnah's authority because it is no longer seen as representing a Tannaitic consensus. At times such attribution is used explicitly as a basis for taking issue with an anonymous Tannaitic teaching. See, for example, b. Beșah 31b. Maimonides uses this strategy here to lessen the authority of the mishnah in Bikkurim by attributing it to an individual, R. Meir-justifiably so, given the Yerushalmi's attestation of R. Judah's dissenting view.

64 Gen. Rab. 39:14 and elsewhere.

65 See Gen. Rab. 39:8.

66 y. Bik. 1:4, 64a. 
become proselytes. ${ }^{67}$ God's promise to grant the land of Canaan to Abraham's descendants as their inheritance ${ }^{68}$ would therefore apply to any and all of his progeny, including his spiritual progeny among the nations, i.e., proselytes. Consequently, in opposition to the Mishnah's view, R. Judah saw no reason why a convert could not recite the first fruits declaration with its statement that "I have entered the land that the Lord swore to our fathers to assign us." 69

This understanding of R. Judah's rationale is reflected in Maimonides' formulation of R. Judah's view in MT:70 "A proselyte brings the first fruits and recites the declaration, for it was said to Abraham, 'I have made you the father of a multitude of nations. ${ }^{71}$ Thus, Abraham is the father to all of the world's inhabitants who enter under the wings of the Divine Presence. And it was to Abraham that the promise was initially made that his children would inherit the land." 72

R. Judah presumably sees Abraham's role as a father to "[those] who enter under the wings of the Divine Presence," i.e., proselytes, ${ }^{73}$ as secondary to his identity as the progenitor of the people of Israel. Proselytes are, in effect, Abraham's adoptive progeny who are absorbed into his biological family. Maimonides, on the other hand, portrays converts not as auxiliary members of Abraham's clan but rather as constituent elements of an Abrahamic faith community $\left(5^{-7}\right)$. This portrayal is a corollary of Maimonides' depiction of Abraham as proselytizer rather than patriarch. A striking consequence is that Abraham is described as father only to those of his descendants "who are worthy in that they follow in his ways," rather than to all of his progeny (7). In other words, biological descent is an insufficient basis for claiming Abraham as one's father if one does not also share his commitment to monotheism. ${ }^{74}$

67 Cf. Gen. Rab. 49:2, where God's decision to inform Abraham of Sodom's impending doom (Gen 18:17) is explained as being a consequence of his having been designated the father of all nations. "Does one judge a son," says the midrash, "without the [knowledge of his] father!?"

68 Gen 12:7.

69 Deut 26:3.

$70 \quad$ Laws of First Fruits 4:3.

71 Gen 17:4.

72 Maimonides draws upon R. Judah's argument when discussing the formula "[the land that] You have given as an inheritance to our ancestors" in section 8 of the responsum. He cites God's promise of the land to Abraham in Gen 13:17 (rather than Deut 26:3, the verse he cites in мт loc. cit.) and argues that it extends to Abraham's followers, among them converts, as well.

73 See n. 19 above.

74 See $n .32$ above. 
Maimonides' characterization of Abraham in this responsum is consistent with the portrayal in мт: ${ }^{75}$

[Abraham] began publicly declaring and informing the entire world that there is but one God in the Universe and that it is proper to worship Him [exclusively]. He continued to preach and to gather the masses, traveling from city to city and from kingdom to kingdom, until he reached Canaan where he proclaimed [the existence of the One God], as Scripture states, "And he proclaimed the name of God, Master of the Universe."76 When the masses crowded around him seeking to understand his words he instructed each of them until he returned him to the path of truth, until thousands and tens of thousands gathered around him - these are those referred to as the members of Abraham's household. ${ }^{77} \mathrm{He}$ implanted this fundamental principle in their hearts and composed books [concerning the true faith], and imparted these teachings to Isaac. Isaac also established himself as a teacher and instructor [of the masses]. He also taught Jacob and appointed him as a teacher.

Both in мт and in his response to Obadiah, Maimonides foregrounds the motif of Abraham as disseminator of monotheistic doctrine, one which is absent from the biblical narrative. At the same time, he ignores the themes of land and progeny that are central to that narrative. By doing so, Maimonides is able to present Abraham as having been tasked with—or, more accurately, having taken upon himself - a universal mission, and therefore a broadly inclusive one, from the moment that God became known to him. Once Judaism, at least in its origins, is defined as a voluntary community of individuals united by their theological convictions rather than their ethnic origins, there is no reason to view a convert as any less Jewish than one who is born a Jew.

\section{Converts as Members of Two Communities}

However, one aspect of Maimonides' account in the responsum is problematic. If Abraham's mission was only to teach humanity about the God of the Universe and his Oneness, what need would there be for a (former) Muslim like Obadiah ${ }^{78}$ to convert to Judaism in order to become his disciple? ${ }^{79}$ This

$75 \quad$ Laws concerning Idolatry 1:3.

76 Gen 21:33. Maimonides recasts the verse's description of Abraham's personal call to God as a record of a public proclamation meant to bring the masses to the true faith.

77 See $n .32$ above.

78 See Blau, 2:548 n.1.

79 It is true that the midrash ( $\mathrm{nn} .64$ and 65) speaks of Abraham and Sarah actually conver- 
difficulty is only intensified by Maimonides' statement elsewhere in $\mathrm{MT}^{80}$ and the reassurance he offers Obadiah in another responsum, ${ }^{81}$ that Islam is not an idolatrous religion. ${ }^{82}$

To understand Maimonides' intent, we need to compare his words here with the continuation of the MT narrative, which follows:

[Jacob] taught others and fortified [the beliefs] of all those who gathered around him. He also taught all of his children. He chose Levi and appointed him as the leader. He established him [as the head of] the academy to teach [members of Jacob's clan] the way of the Lord and to observe Abraham's directive.

[Jacob] commanded his sons that the leadership should not depart from the descendants of Levi, so that the teachings would not be forgotten. This [movement] proceeded and gathered strength among the descendants of Jacob and those who joined them, until there arose a nation on the face of the globe that knew God.

When the people of Israel extended their stay in Egypt, however, they learned from [the Egyptians'] deeds and began worshiping the stars as they did, with the exception of the tribe of Levi, who clung to the directive of the patriarchs [to worship the One God]. The tribe of Levi never served false gods.

Within a short time, the fundamental principle that Abraham had implanted [in the hearts of his followers] would have been uprooted, and the descendants of Jacob would have returned to straying after humankind's false beliefs. Because of God's love for us, and to uphold the promise He made to Abraham, our patriarch, He designated Moses, our Teacher, as the master of all prophets, and sent him [to redeem the people of Israel]. After Moses, our Teacher, prophesied, and God chose Israel as His inheri-

ting, מגייר|מגיירת, their followers. In general, rabbinic sources, do not speak of Abraham having gentile followers who accepted monotheism. This notion originates with Maimonides.

It is worth noting here the Quranic teaching that there is no need to be a Christian or a Jew but only, and most crucially, to become a follower of Abraham by rejecting idolatry (Sura 2, v. 135).

8o Laws of Forbidden Foods 11:7.

$81 \quad$ No. 448 (see n. 12).

82 Indeed, Kaplan, "Singularity," xx n. 28, notes that, given that Maimonides regarded Muslims as orthodox monotheists, it would follow from Maimonides' description of the Abrahamic community in this responsum that he would regard Muslims as members of that community as well. 
tance, $\mathrm{He}^{83}$ crowned them with the commandments and instructed them in the ways of divine service, [and(?)] the laws concerning idolatry and all those who stray after it.

$\mathrm{We}^{84}$ can see that Maimonides speaks here of two separate faith communities (in addition to what Lawrence Kaplan calls the ethnic-historical community of Israel, which will be discussed further on). The first, described at the beginning of the MT narrative, consists of Abraham and his disciples, at the core of which are his descendants, who take up his role as teacher and instructor. This community is unable to sustain itself. As Kaplan notes, ${ }^{85}$ apparently at some point the community of disciples who were not members of Abraham's family ceased to exist; in any case, they disappear from Maimonides' narrative. All that is left of the original community is Abraham's descendants, and during their sojourn in Egypt most of them fall prey to the idolatrous ways of the Egyptians. It is only through the persistent embrace of the true faith by the Levites, Moses' prophecies, the Exodus from Egypt and the Revelation at Sinai that Israel as a whole is restored to the true faith.

In his responsum, on the other hand, Maimonides speaks of the Abrahamic community and the people of Israel synchronically as well as diachronically. As Kaplan suggests, Maimonides seems to be speaking of three communities: "1) the Abrahamic community; 2) the people Israel, as an ethnic-historical community, grounded in historical experience and the memory of the exile and the redemption from Egypt; and 3) the people Israel as the spiritual-political, Mosaic community, distinguished from all other peoples by virtue of receiving the divine Mosaic law."86 Maimonides delineates and discusses each community separately - the first in detail in sections $5^{-7}$, the second in section 9 , and the third in section 11. In sections 6 and 7 , however, he conflates the first and the third (and in a sense the second as well, through mention of Abraham's descendants) designating converts, who have chosen to join the third community, as members of the first community as well: "Therefore, throughout the generations whoever converts to Judaism and whoever confesses the unity of the Divine Name, ${ }^{87}$ as it is prescribed in the Torah, is counted among the

83 I understand the antecedent to be God, though it is not impossible that it is Moses.

84 As will be evident from my notes, the remarks that follow draw heavily upon Lawrence Kaplan's analysis of the passages in мт and Maimonides' responsum. See in particular Kaplan, "Singularity," xiii-xxi.

85 "Singularity," xix.

86 "Singularity", xx n. 29.

87 See the following note. 
disciples of Abraham our Father, peace be upon him" (6). Converts like Obadiah are members of the first community, but not its only members. ${ }^{88}$

Further on, Maimonides emphasizes Obadiah's status as a member of the third community as well. Through his acceptance of the Torah he becomes as fully a member of this community as were the Israelites who were present at Sinai and their descendants. Although it was the ethnic-historical people of Israel who received the Torah, they were able to enter-or, rather, becomethe third community only through the process of conversion.

This emerges from section 11 of the responsum, where Maimonides says that God "brought us [= ethnic-historical Israel] under the wings of the Divine Presence, us and all proselytes, and gave to all of us one Law." Maimonides is alluding here to a rabbinic tradition that the Israelites who left Egypt had to undergo a conversion process before they were fit to receive the Torah. In support of this assertion Maimonides cites Numbers 15:15: "One law shall there be both for you of the congregation, and also for the stranger that sojourns with you, there shall be one law for you and for the ger, a law forever in your generations; as you are, so shall the stranger be before the Lord." In its biblical context

88 Kaplan, "Singularity," xix n. 26, observes that this point is obscured in Glatzer's and Twersky's translations of a phrase in the passage cited above; I have translated it as "thus, whoever converts to Judaism and whoever confesses the unity of the Divine Name [... is counted among the disciples of Abraham]." Glatzer translates this passage as "thus he who becomes a proselyte and confesses the oneness of God." Twersky's translation is "whoever adopts Judaism and confesses the unity of the divine name." Both of these translations ignore the word וכל, inaccurately conveying the idea that for Maimonides only those who convert are counted among those who confess the divine name.

Much more disturbing is the fate that a subsequent sentence suffers at the hands of Shilat. In Blau's edition (2:549) the line reads: "It emerges that Abraham ... is the father of his disciples and [of] all those who become proselytes (וכל גר שיתגייר)." In Shilat's edition $(1: 234,1.8)$ the text reads וזהם כל גר שיתגייר, which translates as "they being all those who become proselytes"; that is to say, only proselytes, and not gentile monotheists, are viewed as Abraham's disciples. In his introduction Shilat states that although for each text he follows faithfully the manuscript he considers most preferable, "המשובח ביותר", his notes mention those textual variants that are substantively significant, "משמעותיים מבחינת הלשון" (1:12). Blau's version conveys a very different meaning from Shilat's, yet it is not mentioned in Shilat's notes. Menachem Kellner cites this as an example of what he claims is Shilat's tendency to minimize the universalist aspects of Maimonides' theological views. See Menachem Kellner, "Farteitcht un Farbessert (On "Correcting" Maimonides)," in Meorot: A Forum of Modern Orthodox Discourse 6, no. 2 (Marheshvan 5768/2007): 9-11 and esp. n. 26.

Ironically, Kellner himself blunts the universalist thrust of the phrase discussed at the beginning of this footnote, albeit inadvertently. Despite the fact that Shilat's version of the passage discussed at the beginning of this footnote includes the word וכל Kellner (p. 10) mistranslates this word exactly as Twersky does. 
"law" refers to the regulations concerning voluntary sacrifices, and ger refers to a sojourner, a resident alien. It permits resident aliens to bring voluntary sacrifices while requiring that they be offered in accordance with the strictures prescribed previously (vv. 1-11) for Israelites.

The rabbis do not read the verse in this way. They understand ger as meaning "proselyte" - clearly not the original meaning of the word since the institution of conversion did not exist in biblical times. According to the Talmud, the laws in question are the rituals required for conversion: immersion, circumcision for males, and, in Temple times, a sacrifice. The rabbis assume that the Israelites underwent this conversionary process in preparation for receiving the Torah. The statement "as are you so shall the ger" - that is, a proselyte - "be before the Lord" means, therefore: "Just as your ancestors entered the covenant by means of circumcision, immersion, and sacrificial offerings, so too, converts shall enter the covenant by means of circumcision, immersion, and sacrificial offerings." 89 By retrojecting the institution of conversion the sages provide it with biblical support and normative status.

Maimonides, while essentially adopting the rabbinic reading of Numbers 15:15, expands and reshapes it considerably. First, he interprets "law" as referring to the entire corpus of biblical commandments. Second, he seems to read "it shall be a law for all time" as meaning that at the moment of Revelation, the Torah was given not only to those present and their descendants but also, prospectively, to any and all who would later choose to enter the covenant. In effect, a convert is seen as accepting the Torah given to him in potentia at Sinai rather than embracing it unilaterally.

We can now make sense of Maimonides' historical-theological narrative as it appears in the responsum and its relevance to Obadiah's status as a Jew. Obadiah would not have needed to convert had he wished only to join the Abrahamic community of monotheists. Nonetheless, his conversion entailed the acceptance of Abrahamic theology, and as such, Maimonides points out, Obadiah was qualified to use formulae referring to Abraham and the patriarchs as his ancestors..$^{90}$ However, Obadiah was not content to be solely a member of the Abrahamic community. His conversion was motivated by a desire to

\footnotetext{
89 b. Ker. ga.

9o The fact remains that Maimonides' description of Abraham's proselytizing as "gather[ing] many under the wings of the Divine Presence" (5) does not sit well with his use of this phrase elsewhere. In all other instances it refers to conversion proper, not simply accepting the belief in the One God and His unity; see n. 2o. Perhaps Maimonides is speaking prospectively; it is due to Abraham that all those who convert are brought under the wings of the Divine Presence.
} 
join the third community as well. This community was initially the product of communal conversion and was based on a covenantal acceptance of the Torah in addition to a commitment to monotheistic belief. As a consequence of becoming a proselyte Obadiah simultaneously entered into the Abrahamic community and the covenant between God and Israel. Maimonides posits that Obadiah's participation in that covenant is relevant with regard to the other liturgical phrases about which he inquired.

It may be that Maimonides' linking of converts with the original Abrahamic community may serve a purpose beyond justifying the use of formulae mentioning the patriarchs. In Maimonides' view, a convert connects himself trans-historically to the faith community that preceded the formation of the covenantal community at Sinai. Thus, a convert can be seen as a disciple of Abraham who adhered to his teachings even after Abraham's other disciples had lapsed into idolatry. In the act of conversion, he arrives at Sinai, as it were, as a spiritual member of the Levitic community, those who held fast to monotheistic beliefs while their fellow Israelites strayed after foreign gods. Obadiah is not, therefore, a latecomer to the Sinaitic covenant, but, on the contrary, a faithful member of the first community who now joins the third. This depiction of the convert is particularly compelling in Obadiah's case given that Maimonides regarded him as having been a monotheist while still a Muslim.

\section{Proselytes as Members of the Chosen People}

In sections 10 and 11 Maimonides addresses the question of whether Obadiah could recite formulae referring to Israel's election and the Revelation at Sinai. These phrases present two different challenges. In the case of election, it was ethnic-historical Israel that God separated from the other nations because of a promise made to Abraham concerning his progeny. Maimonides himself acknowledges this in the passage in MT passage quoted above: "Because of God's love for us, and to uphold the promise He made to Abraham ... [He] chose Israel as His inheritance." The Revelation at Sinai was, leaving aside its perpetual significance, also an historical event involving ethnic-historical Israel. Moreover, election and revelation were intertwined; it was God's election of Israel that led to the Torah being given to them exclusively. Obadiah could not claim ethnic ties to the nation that was chosen to be God's people and that stood at Sinai.

Maimonides' response to these challenges is to frame both Israel's election and the Sinaitic covenant as a consequence of their status, as noted above, as the sole continuators of the Abrahamic faith community. The fact that the Israelite nation, even as most of its members fell away from monotheistic belief and worship during their sojourn in Egypt, contained within it the last rem- 
nant of Abraham's faith community, the Levites, was thus a crucial factor in God's election of the Israelite nation. Moreover, in order to become to be God's chosen people, the nation as a whole had to return to belief in the One God. Consequently, they had to be separated from the Egyptians, who had led them astray, and be given the Torah. The commandments contained in the Torah are, as Maimonides explains in his Guide of the Perplexed, a means of insuring "that every [Jew] ... achieves his first perfection, [meaning] the soundness of beliefs and ... correct opinions through which ultimate perfection is achieved."91

Like the Israelites, Obadiah, argues Maimonides, had undergone a process of separation that, like the God's liberation of the Israelites, was theologically motivated. Obadiah had separated himself from Islam and, as a consequence, no doubt had to sever many if not all familial and communal ties. In sections 10 and 11 Maimonides equates Obadiah's act of withdrawal from his faith and his people with the Exodus from Egypt, the beginning of Israel's process of separation. Like the people of Israel, then, Obadiah undergoes separation as a prelude to conversion.

It is striking that Maimonides describes Obadiah as having been chosen and separated "from the nations" by God (11). In doing so he seems to ignore if not deny the reality that Obadiah's conversion was the consequence of a conscious and volitional decision on his part, a fact that Maimonides actually highlights in his description elsewhere of Obadiah's spiritual journey. ${ }^{92}$ Apparently, just as Maimonides sees Obadiah's conversion as the acceptance of a pre-existent offer of the Torah at Sinai to all future converts, he sees Obadiah's decision to separate himself from his past as accepting a destiny divinely preordained for him and his fellow proselytes.

\section{Homiletics: Articulating the Heart of the Problem and Engaging Obadiah's Heart}

Maimonides turns to homiletics twice. The first instance is after he has dealt with the difficult question of whether Obadiah may recite "You who have brought us out of the land of Egypt" and "You who have performed miracles for our ancestors" (9). These formulae would seem inappropriate for someone not a descendant of the Israelites who experienced God's wonderous and redemp-

91 Book III, Chapter 27. The translation is taken from Maimonides, The Guide of the Perplexed, trans. with an introduction and notes by Shlomo Pines with an introductory essay by Leo Strauss (Chicago: University of Chicago Press, 1963), 511.

Responsum 448 (2:728; Shilat, 1:241, lines 5-6). I discuss this passage further on. 
tive presence in Egypt and beyond. Consequently, Maimonides concedes that it would be reasonable for Obadiah not to include these formulae in his prayers and blessings (9). Not willing to let this ruling stand uncontested, however, Maimonides immediately shifts from acceptance to approval of Obadiah's use of the standard liturgical formulae, positing that one who joins the people of Israel has the right to claim its sacred history as his own.

The fact remains that even this temporary admission represents a chink in the protective armor with which Maimonides has clothed Obadiah's Jewish status. It is perhaps awareness of this that impels Maimonides specifically at this point to articulate on Obadiah's behalf, as it were, his presumed, albeit unstated, anxiety about his authenticity as a Jew. To do so Maimonides employs a verse that gives voice to the fears of a foreigner seeking to associate himself not only with the God of Israel but with His people as well: "Let not the foreigner who has attached himself to the Lord say, "The Lord will keep me apart from His people'." 93

The use of this verse is particularly apt in at least four respects. First, the term that I have translated as "foreigner" is בן הנכר. The basis for the foreigner's potential disqualification is genealogical; he is of foreign, non-Israelite stockas is Obadiah. Second, the verse describes a tension between the foreigner's unqualified attachment to the God of Israel on the one hand and his uncertainty about his bond with God's people on the other-which is precisely Obadiah's predicament. Third, the concern of the foreigner, translated as "the Lord will keep me apart," is הבדל יבדילני. The verb bdl is used in the liturgical formula "who has distinguished us," one of the formulae about which Obadiah inquired. ${ }^{94}$ Fourth, as James Diamond has so brilliantly noted, ${ }^{95}$ God responds to the foreigner's fear of being kept apart, of being an "outsider," with the promise that "My house shall be called a house of prayer for all peoples." ${ }^{\text {" Oba- }}$ diah's inquiry touches upon the question of his place in God's house of prayer, the synagogue, especially as it concerns his fitness to serve as prayer leader.

Maimonides turns to homiletics a second time after having addressed individually each of the liturgical formulae under consideration; perhaps he hopes that his rhetorical skills will compensate for whatever might be the limitations of his halakhic and theological arguments. Once again, he articulates Obadiah's fear: "Do not consider your origin as inferior," before concluding his theolog-

93 Isa $56: 3$.

94 See sections 3 and 10.

95 Diamond, “Converts," 9-10.

96 Isa 56:7. The language and content of Isa 56:3, 7-9 clearly indicate a polemical engagement with the views expressed in Ezek 44:7-11 and Neh 9:2. 
ical exposition with a homiletical tour de force that brilliantly and radically marginalizes and transcends the issues of land, shared historical experience, and peoplehood:

While we descend from Abraham, Isaac, and Jacob, yours is a direct relationship with Him through whose word the world was created. This is made explicit in [the Book of] Isaiah: "One shall say, I am the Lord's, and another shall call himself by the name of Jacob” (12).

It is precisely the absence of a biological connection with the people of Israel that renders Obadiah's spiritual journey a reenactment of Abraham's-an experience foreclosed to native-born Jews. As Maimonides says in another responsum addressed to Obadiah—borrowing from the language of Genesis 12:1- he is "a disciple of Abraham who left his family and his native land to become a follower of God."97 Maimonides' language in that responsum is suggestively ambiguous. Who is it who left home and family, שהניח אבותיו ומולדתו, in a quest to follow God: Obadiah or Abraham? The answer, of course, is that both did, and presumably Maimonides is intentionally merging his description of Obadiah's journey with that of Abraham's quest, as he does here less explicitly. ${ }^{98}$

\section{The Issue of Discrepancies}

In sum, it may be said that this responsum constitutes a serendipitous instance of Maimonides' sincerely held view of Judaism being perfectly suited to provide support and validation to his petitioner. Thus, while Maimonides may use the strategies outlined above in framing his response, at no point does he sacrifice his integrity as theologian and halakhist to arrive at his conclusion. In this instance Maimonides would seem not to be vulnerable to the charge leveled by Haym Soloveitchik against his Iggeret ha-Shemad in which, according

\footnotetext{
$97 \quad$ See n. 92.

98 Compare James Diamond's slightly different analysis in "Converts," 17-18. Diamond thinks that what sets apart the convert is the certainty that his motives for accepting the covenant and walking in God's ways are pure, as were Abraham's. I find this explanation unconvincing for reasons that I will not enumerate here. My understanding is that Maimonides has in mind the willingness of Abraham and Obadiah to adhere to faith in the One God though it meant leaving hearth and home and defying the beliefs and practices of one's native culture.
} 
to Soloveitchik, Maimonides plays fast and loose with the use and interpretation of rabbinic sources as well as with halakhic methodology. ${ }^{99}$

There is one respect in which Maimonides could be said to be oversimplifying, or even misrepresenting, the Jewish status of a convert. His reassuring words to Obadiah, "There is no difference whatsoever between you and us" (9), ring false. As mentioned above, there are numerous instances in which halakhah assigns converts an inferior status, be it the inability to serve as a judge for halitza ${ }^{100}$ or that they are placed in a separate genealogical category and are therefore allowed to marry mamzerim, who are forbidden to nativeborn Israelites. ${ }^{101}$ Second, while Maimonides concludes here and in мT that converts are to recite the declaration accompanying the bringing of the first fruits to the Temple, he also rules in $\mathrm{MT}^{102}$ that converts are not to recite the declaration concerning tithes, because they have no inheritance in the Land of Israel - precisely the same argument made in the Mishnah for a convert not reciting the declaration over the first fruits. ${ }^{103}$ Third, Maimonides himself notes that it is questionable whether Obadiah could in some sense regard himself as a member of the ethnic-historical nation of Israel, with possible halakhic consequences.

To respond to the second objection, we must consider Maimonides' philosophy of halakhah. As Jose Faur ${ }^{104}$ points out, Maimonides posits that the particulars of halakhah are not always in accord with the canons of logic; the authority of Hazal as the tradents and interpreters of Torah obligates us to

99 See Haym Soloveitchik, "Maimonides' 'Iggeret ha-Shemad': Law and Rhetoric," in Rabbi Joseph H. Lookstein Memorial Volume, ed. L. Landman (New York: Ktav Publishing House, 1980), 281-319; and David Hartman's initial dissent in Abraham Halkin and David Hartman, Crisis and Leadership: Epistles of Maimonides (Philadelphia:Jewish Publication Society, 1985), 46-83. For an analysis of the dispute between Soloveitchik and Hartman's dissent, see Yair Lorberbaum and Haim Shapira, "Maimonides' Epistle on Martyrdom in the Light of Legal Philosophy," Diné Israel 25 (2008): 123-169. A bibliography of Soloveitchik's and Hartman's writings on this subject can be found there on p. 124 n. 1. Herbert Davidson adduces the problematic halakhic methodology and reasoning evinced by the epistle's author as evidence that he is not in fact Maimonides; see Davidson, Moses Maimonides: The Man and His Works (Oxford: Oxford University Press, 2005), 501-509 and especially 508.

100 See MT, Laws of Levirate Marriage 4:5.

101 See мт, Laws of Forbidden Relations 15:7.

102 MT, Laws of the Second Tithe 11:17.

103 Commentaries there (Laws of the Second Tithe, loc. cit.) note this contradiction and attempt to resolve it.

104 Jose Faur, Studies of Maimonides' Mishneh Torah [Heb.] (Jerusalem: Mossad HaRav Kook, 1978), 142-147. 
follow their rulings nonetheless. The apparent logical inconsistency of Maimonides allowing and obligating proselytes to recite the miqra bikkurim on the one hand and excluding them from vidui ma'aserot should not, therefore, be regarded as problematic.

Nonetheless, the question remains: How can Maimonides claim equal Jewish status for Obadiah in the face of a number of halakhot suggesting a diminished status for proselytes? I would like to suggest an admittedly speculative answer that draws upon both the content and structure of Maimonides' response to Obadiah.

Maimonides' segregation of the halakhic material from his theological reflections might reflect a view that the nature of Jewish identity transcends and is separate from matters of halakhah. Specifically, Maimonides could be seen as implying that while his ruling on the question was consistent with his characterization of Obadiah's Jewish status, that status was in no way contingent upon that ruling. In Maimonides' view, the covenantal community created at Sinai was rooted in the non-ethnic Abrahamic faith community, and the transition from a theologically-based community to one based on divine commandments was accomplished through a community-wide conversionary process. It is true that God chose a particular nation to become His covenantal partners, but Maimonides regards the ethnicity of Israel as a reason for having been chosen rather than an essential definitional element of that chosenness. Therefore, anyone willing to adhere to Abrahamic monotheism and to undergo the conversionary process vital to joining the covenantal community is to be considered the equal of native-born Jews.

This may be part of what motivated Maimonides' placing his exposition of the Talmudic sources at the end of the responsum. I suggested above that the positioning of the Talmudic material at the end of the responsum may have been motivated in part to downplay its significance, thereby forestalling the possibility that it would lead Obadiah to question both Maimonides' assurances in general and his ruling in particular. What I am arguing now is that ideological convictions as well as strategic considerations guided his segregation and placement of the halakhic material.

The writing of a responsum presents many challenges to the poseq. He or she must identify the relevant Talmudic material and analyze it in light of the interpretations of earlier commentaries. Previous responsa addressing the same or related issues must also be considered. However, these are not the only factors that come into play. Consciously or otherwise, his or her views on matters of 
theology, social policy, gender roles— to name but a few-may determine his or her ruling or at least some of its particulars. In addition, a poseq is responding to a particular petitioner or petitioners: an individual, two or more disputants, perhaps a community. To be effective poseqim they must take their audience into account. Part of doing so is to intuit when there are significant psychological, social, or political factors that have not been spelled out in the question.

We have seen how Maimonides, both because of his own theological convictions and through a sensitivity to his questioner, wrote a response that exhibits, both in style and substance, halakhic and theological sophistication and creativity as well as psychological acuity. This last aspect of pesaq, which can be found in responsa throughout the ages, has not been given the attention it deserves. It is my intention to address this issue further in the future, and I hope that this article will inspire others to do the same.

\section{Bibliography}

Adler, Aharon. "Maimonides' Stance toward the Jerusalem Talmud" [in Hebrew]. In Memorial Volume for R. Joseph ben David Kafih [in Hebrew]. Edited by Henil Seri and Zohar Amar, 202-235. Ramat Gan: Bar-Ilan University Press, 2001.

Blau, Joshua ed. and trans. Maimonides'Responsa [in Hebrew]. 3 vols. Jerusalem: Hevrat Meqiṣe Nirdamim, 1961.

Cooper, Levi. "From the Classics: 'God of our Ancestors': Biological Ancestry and Spiritual Roots in the Prayers of Converts." Building Jewish Identity 7, no. 2 (Winter 20o9). Online: https://www.lookstein.org/journal/classics-god-ancestors-biological -ancestry-spiritual-roots-prayers-converts/.

Davidson, Herbert. Moses Maimonides: The Man and His Works. Oxford: Oxford University Press, 2005.

Diamond, James A. Converts, Heretics, and Lepers. Notre Dame: University of Notre Dame Press, 2007.

Diamond, James A. "Maimonides and the Convert: A Juridical and Philosophical Embrace of the Outsider." Medieval Philosophy and Theology 11, no. 2 (2003): 125-146.

Elon, Menachem. Jewish Law: History, Sources, Principles. Translated by Bernard Auerbach and Melvin J. Sykes. 4 vols. Philadelphia: Jewish Publication Society, 1994.

Faur, Jose. Studies of Maimonides' Mishneh Torah [in Hebrew]. Jerusalem: Mossad HaRav Kook, 1978.

Fixler, Dror. "Maimonides' Stance toward the Jerusalem Talmud as Reflected by His Commentary to Tractate Pe'ah" [in Hebrew]. Netu'im 16 (2010): 95-109.

Glatzer, Nahum N., ed. The Judaic Tradition. revised ed. Springfield, NJ: Behrman House, 1969 . 
Goldschmidt, Daniel. Meḥqerē Tefillah u-Fiyyut. Jerusalem: Magnes, 1980.

Guttmann, Michael. “The Decisions of Maimonides in his Commentary on the Mishna." Hebrew Union College Annual 2 (1925): 229-268.

Halbertal, Moshe. Maimonides: Life and Thought. Translated by Joel Linsider. Princeton: Princeton University Press, 2014.

Halkin, Abraham, and David Hartman. Crisis and Leadership: Epistles of Maimonides. Philadelphia: Jewish Publication Society, 1985.

Kafih, Yosef, ed. and trans. Maimonides' Mishnah Commentary [in Hebrew]. 3 vols. Jerusalem: Mossad Harav Kook, 1963.

Kaplan, Lawrence. "Maimonides on the Singularity of the Jewish People." Daat 15 (1979): English section, v-xxvii.

Kasher, Menahem Mendel, ed. Talmudic Encyclopedia [in Hebrew]. 40 vols. so far. Jerusalem: Yad Harav Herzog, 1947-.

Kellner, Menachem. "Farteitcht un Farbessert (On "Correcting" Maimonides)." Meorot: A Forum of Modern Orthodox Discourse 6, no. 2 (Marheshvan 5768/2007): 1-13.

Kellner, Menachem. Maimonides on Judaism and the Jewish People. Albany, NY: SUNY Press, 1991.

Lieberman, Saul. Tosefta Ki-Fshuțah. 10 vols. 3rd ed.Jerusalem:Jewish Theological Seminary, 2001.

Lorberbaum, Menachem. "Maimonides' Letter to Ovadyah: An Analysis." S'vara 3, no. 1 (1993): 57-66.

Lorberbaum, Yair, and Haim Shapira. “Maimonides' Epistle on Martyrdom in the Light of Legal Philosophy." Diné Israel 25 (2008): 123-169.

Maimonides. The Guide of the Perplexed. Translated with an introduction and notes by Shlomo Pines with an introductory essay by Leo Strauss. Chicago: University of Chicago Press, 1963.

Posner, Philip Matoff. "Maimonides' "t'shuva” to Ovadyah the Proselyte." ccaR Journal 6o, no. 3 (2013): 185-202.

Shilat, Isaac, ed. and trans. Maimonides' Epistles [in Hebrew]. 2 vols. Jerusalem: Ma'aliyot Press, 1988.

Soloveitchik, Haym. "Maimonides' 'Iggeret ha-Shemad': Law and Rhetoric." In Rabbi Joseph H. Lookstein Memorial Volume. Edited by L. Landman, 281-319. New York: Ktav Publishing House, 1980.

Twersky, Isadore. Introduction to the Code of Maimonides (Mishneh Torah). New Haven: Yale University Press, 1980.

Twersky, Isadore. A Maimonides Reader. New York: Behrman House, 1972. 